\title{
Corynebacterium jeikeium Dormant Cell Formation and Photodynamic Inactivation
}

\author{
Margarita Shleeva*, Alexander Savitsky and Arseny Kaprelyants \\ Federal Research Centre "Fundamentals of Biotechnology" of the Russian Academy of Sciences, A.N. Bach Institute \\ of Biochemistry, Moscow, Russia
}

Pathogenic non-spore forming bacteria enter a dormant state under stressful conditions, which likely allows them to acquire resistance to various antibiotics. This work revealed the efficient formation of dormant "non-culturable" (NC) Corynebacterium jeikeium cells in stationary phase upon gradual acidification of the growth medium. Such cells were unable to form colonies and existed in a prolonged stationary phase. At an early

OPEN ACCESS

Edited by:

Fabian Cieplik,

University Medical Center

Regensburg, Germany

Reviewed by:

Joanna Nakonieczna,

Intercollegiate Faculty

of Biotechnology of University of Gdańsk and Medical University

of Gdańsk, Poland

Alessandra Nara De Souza

Rastelli,

São Paulo State University, Brazil

*Correspondence:

Margarita Shleeva

mshleeva@inbi.ras.ru

Specialty section:

This article was submitted to

Antimicrobials, Resistance

and Chemotherapy,

a section of the journal

Frontiers in Microbiology

Received: 13 September 2020

Accepted: 30 November 2020

Published: 18 December 2020

Citation:

Shleeva M, Savitsky A and

Kaprelyants A (2020)

Corynebacterium jeikeium Dormant Cell Formation and Photodynamic

Inactivation.

Front. Microbiol. 11:605899. doi: 10.3389/fmicb.2020.605899 stage of dormancy (approximately 14 days post-inoculation), dormant cells are able for resuscitation in liquid medium. However, those stored for long time in dormant state needed addition of supernatant taking from active $C$. jeikeium cultures for successful resuscitation. NC cells possessed low RNA synthesis and significant tolerance to antibiotics (rifampicin and vancomycin). They also accumulated free porphyrins, and 5aminolevulinic acid addition enhanced free porphyrin accumulation which makes them potentially sensitive to photodynamic inactivation (PDI). PDI of dormant bacteria was accomplished by exposing cells to a $565 \mathrm{~nm}$ wavelength of light using a SOLIS-4C lightemitting diode for $60 \mathrm{~min}$. This revealed that increased porphyrin concentrations were correlated with elevated PDI sensitivity. Results shown here demonstrate the potential utility of employing PDI to minimize levels of dormant, persistent corynebacteria and the C. jeikeium dormancy model developed here may be useful for finding new drugs and techniques for combatting persistent corynebacteria.

Keywords: Corynebacterium jeikeium, resuscitation, porphyrin, photodynamic inactivation, dormant bacteria, resistance

\section{INTRODUCTION}

Interest in the study of dormant forms of non-sporulating bacteria is caused, on one hand, by the desire to understand long-term bacterial survival mechanisms under conditions that are not conducive to growth that occur in natural ecosystems (El-Registan et al., 2006; Lennon and Jones, 2011). On the other hand, the occurrence of dormancy is associated with pathogen persistence via the formation of antibiotic-resistant, persistent cells (Keren et al., 2004; Zhang, 2004; Lewis, 2007). The problem of antibiotic resistance and the emergence of antimicrobial resistant strains has become especially important in connection with current infectious disease expansion. For example, resistance has been observed in Staphylococcus aureus, which is able to form cells with increased antibiotic resistance, which enhances persistence in the host organism and causes chronic or recurrent infections (Chambers and Deleo, 2009). A similar phenomenon has also been described in Mycobacterium tuberculosis (Kaprelyants et al., 2018). 
The bacterial transition to a dormant state has been documented in experimental studies that described the process in a number of non-sporulating bacteria (Kaprelyants et al., 1993). Further, dormant bacterial cells may develop "non-culturability" (NC) (a term which reflects the inability to form colonies on agar plates), which prevents the cells from being detected in vivo using routine plating procedures (Roszak and Colwell, 1987; Cellini et al., 1994; Porter et al., 1995; Kell et al., 1998; Barer and Harwood, 1999; Tholozan et al., 1999; Biketov et al., 2000; Currás et al., 2002; Shleeva et al., 2002; Mukamolova et al., 2003; Wood et al., 2005; Lee et al., 2007). For many non-sporulating gramnegative and gram-positive bacteria, including non-pathogenic relatives of pathogens, morphologically differentiated dormant forms have previously been described (Cellini et al., 1994; Currás et al., 2002; Shleeva et al., 2002, 2004; Lee et al., 2010; Mulyukin et al., 2010). Studying the possible persistence and development of antibiotic resistance of other pathogenic and conditionally pathogenic bacteria, including representatives of the genus Corynebacterium is also relevant (Blokpoel et al., 2005; Tauch et al., 2005; Soriano et al., 2009; Olender, 2012).

Many corynebacteria are pathogenic (Bernard, 2012). Corynebacteria of the species Corynebacterium diphtheriae, which produce a very strong exotoxin, are the causative agents of one of the most famous human infections, diphtheria. So-called non-diphtheria corynebacteria (Corynebacteria non-diphtheriae) C. ulcerans and C. pseudotuberculosis cause diphtheria-like diseases that include pseudomembranous pharyngitis, moderate pharyngitis, otitis, lymphadenitis and skin ulcers. C. minutissimum is a causative agent of erythrasma and chronic pseudomycosis. C. amycolatum, C. urealyticum, and C. striatum are particularly resistant to penicillins, aminoglycosides and quinolones. C. jeikeium strains are causative agents of hospital infections. C. jeikeium is responsible for a number of nosocomial infections such as endocarditis, device-connected infection, osteomyelitis (van der Lelie et al., 1995; Mookadam et al., 2006). The bacteria has often found in cancer patients with compromised immune system, inserted in medical instruments, skin lesions, and after antibiotic therapy (Funke et al., 1997). A high mortality rate was documented for C. jeikeium sepsis in hematological patients (van der Lelie et al., 1995), and immunocompromised patients carrying prosthetic valves or catheters are particularly susceptible to infection. Further, the curing of C. jeikeium frequently limited by developing of multidrug-resistance of the bacteria (Olson et al., 2009; Ifantidou et al., 2010).

Whilst the phenomenon of dormancy in non-sporulating bacteria is extensively studied for many years, corynebacteria dormancy in vivo and in vitro did not attract much attention. Only one model has been used to assess dormant forms of C. pseudodiphtheriticum, which is based on the fivefold limit of the nitrogen source provided in growth media (Mulyukin et al., 2014).

After infecting humans, bacteria are typically captured by macrophages where they are influenced by a number of stresses including low $\mathrm{pH}$, elevated levels of the active forms of oxygen and nitric oxide and the activity of lysosomal hydrolases (Rook et al., 2001; Hacker et al., 2016; BoseDasgupta and Pieters, 2018).
However, some bacteria, such as M. tuberculosis (Deretic and Fratti, 1999) and C. ulcerans (Hacker et al., 2016), can maintain their viability within macrophages despite these harmful factors. Therefore, naturally induced stressful conditions are likely to be factors that are also useful for inducing a dormant state in vitro. M. tuberculosis (Shleeva et al., 2011) and non-pathogenic M. smegmatis (Kudykina et al., 2011) transition to dormant, non-culturable, persistent states in response to the gradual acidification of their environments, therefore, we may suggest that slow decrease in $\mathrm{pH}$ levels may result in induction of dormancy in corynebacteria, which, like mycobacteria, belong to the order Actinomycetales.

In order to cure chronic infections caused by dormant forms of pathogens, new ways should be established (Kaprelyants et al., 2018). In this regard, application of physical factors seems to be promising in order to destroy metabolically passive dormant bacterial forms. Recently we found that significant concentrations of the intermediates participating in protoporphyrin biosynthesis were present in dormant forms of M. smegmatis (Nikitushkin et al., 2016), a fast-growing bacterium which is genetically close to $M$. tuberculosis, These findings suggested that dormant bacteria may be killed by photodynamic inactivation (PDI) when fluorescent porphyrins serve as intracellular photosensitizers. Studies have also demonstrated the photoinactivation of dormant mycobacterial forms in vitro in the rapidly growing, tuberculosis-related pathogenic strain, M. smegmatis (Shleeva et al., 2019b, 2020).

The goal of this study was to find if C. jeikeium are able to form dormant cells as a result of slow decrease of $\mathrm{pH}$ level of growth medium in stationary phase. We also tested whether the stimulation of endogenous porphyrin production in dormant corynebacteria enhances their sensitivity to photodynamic inactivation (PDI).

\section{MATERIALS AND METHODS}

\section{Organisms and Media}

The C. jeikeium K411 strain (from State collection of pathogenic microorganisms FSBI Scientific Center for Expert Evaluation of Medicinal Products of the Ministry of Health of the Russian Federation) was grown in TSB broth (Himedia, India) at $37^{\circ} \mathrm{C}$ for 20-24 h while stirring (200 rpm). A $0.2 \mathrm{~mL}$ inoculum was added to $100 \mathrm{~mL}$ developed by us 2 AS medium $\left(10^{5}\right.$ cells $\left./ \mathrm{mL}\right)$ with the following composition: $20 \mathrm{~g} / \mathrm{L}$ glucose; $0.125 \mathrm{~g} / \mathrm{L}$ $\mathrm{MgSO}_{4} \times 7 \mathrm{H}_{2} \mathrm{O} ; 1.5 \mathrm{~g} / \mathrm{L} \mathrm{NaCl} ; 2.5 \mathrm{~g} / \mathrm{L}\left(\mathrm{NH}_{4}\right)_{2} \mathrm{SO}_{4} ; 13.6 \mathrm{~g} / \mathrm{L}$ $\mathrm{KH}_{2} \mathrm{PO}_{4} ; 0.44 \mathrm{~g} / \mathrm{L}$ histidine (Sigma); $4.0 \mathrm{~g} / \mathrm{L}$ glutamic acid (Sigma); $8 \mathrm{~mL}$ trace element solution; and $0.1 \%$ Tween-80. The media was $\mathrm{pH}$ adjusted to 6.0 using $\mathrm{NaOH}$. Trace element solution contained $1.0 \mathrm{~g} / \mathrm{L}$ EDTA, $10.0 \mathrm{~g} / \mathrm{L} \mathrm{MgCl}_{2} \times 6 \mathrm{H}_{2} \mathrm{O}$, $0.1 \mathrm{~g} / \mathrm{L} \mathrm{CaCl} 2 \times 2 \mathrm{H}_{2} \mathrm{O}, 0.04 \mathrm{~g} / \mathrm{L} \mathrm{CoCl}_{2} \times 6 \mathrm{H}_{2} \mathrm{O}, 0.1 \mathrm{~g} / \mathrm{L}$ $\mathrm{MnCl}_{2} \times 2 \mathrm{H}_{2} \mathrm{O}, 0.02 \mathrm{~g} / \mathrm{L} \mathrm{Na}_{2} \mathrm{MoO}_{4} \times 2 \mathrm{H}_{2} \mathrm{O}, 0.2 \mathrm{~g} / \mathrm{L}$ $\mathrm{ZnSO}_{4} \times 0.02 \mathrm{~g} / \mathrm{L} 7 \mathrm{H}_{2} \mathrm{O}, \mathrm{CuSO}_{4} \times 5 \mathrm{H}_{2} \mathrm{O}$ and $0.5 \mathrm{~g} / \mathrm{L}$ $\mathrm{FeSO}_{4} \times 7 \mathrm{H}_{2} \mathrm{O}$. A final concentration of $0.1 \%$ Tween 80 was added. The culture was grown at $37^{\circ} \tilde{\mathrm{N}}$ in a shaker (200 rpm) for 13-16 days until a $\mathrm{pH}$ of approximately 5.5 was established. 


\section{Estimation of Viability}

Bacterial suspensions were serially diluted in fresh TSB medium, and three $10 \mu \mathrm{l}$ samples from each dilution were spotted on TSB (Himedia, India) agar containing $0.1 \%$ Tween-80. Plates were incubated at $37^{\circ} \mathrm{C}$ for 5 days. After incubation, the number of the colony forming units (CFUs) present was counted. The limit of detection was $10 \mathrm{CFU} / \mathrm{mL}$.

The same diluted suspensions (100 $\mu \mathrm{L}$ each) were also used for most probable number (MPN) assays and to evaluate cell resuscitation in 48-well Corning microplates containing appropriate medium $(0.9 \mathrm{~mL})$ (see below). Microplates were incubated at $37^{\circ} \mathrm{C}$ for 14 days without agitation. Wells with visible bacterial growth were considered positive. The number of cells that remained intact after exposure to damageinducing effects was also determined microscopically by counting propidium iodide (PI)-negative cells in a Helber's chamber (no less than 10 large fields were counted for each sample).

\section{Measuring Levels of ${ }^{3} \mathrm{H}$-uracil Incorporation to Determine the Metabolic Activity of Cells}

One milliliter samples from cells suspensions were incubated with $1 \mu \mathrm{l}\left[5,6-{ }^{3} \mathrm{H}\right]$ uracil $(10 \mu \mathrm{Ci} ; 0.2 \mu \mathrm{mol}$ in $50 \%$ ethanol) and incubated for $2 \mathrm{~h}$ at $37^{\circ} \mathrm{C}$ with agitation (45$60 \mathrm{rpm})$. Cells were then harvested on glass fiber GFC filters (Whatman, United Kingdom) and washed with $3 \mathrm{~mL} 7 \%$ trichloroacetic acid. Next, cells were washed using $3 \mathrm{~mL}$ absolute ethanol. Air-dried filters were placed in scintillation liquid and incorporated radioactivity was measured using a scintillation counter (Beckman, United States).

\section{Spent Medium Preparation}

Supernatants (SN) with resuscitating activity were obtained from C. jeikeium cultures grown in either TSB or 2AS (initial $\mathrm{pH}$ 7.0) media after consecutive sub-culturing. First, a $0.2 \mathrm{~mL}$ stock culture (stored at $-70^{\circ} \mathrm{C}$ ) was used to inoculate $100 \mathrm{~mL}$ culture medium to produce an initial density of approximately $10^{3}$ cells $/ \mathrm{mL}$. The cultures were incubated overnight with agitation $(100 \mathrm{rpm})$. Cells were sub-cultured by transferring a $0.1 \mathrm{~mL}$ inoculum to $100 \mathrm{~mL}$ fresh medium and cultivating as previously described for 2-30 h. Then cultures were subjected to centrifugation $(12,000 \times \mathrm{g}, 20 \mathrm{~min})$ and sterilization using $0.22 \mu \mathrm{m}$ filters (Whatman). Fifty milliliters volumes of SN produced in this manner were frozen and stored at $-70^{\circ} \mathrm{C}$. C. jeikeium growth stimulating activity of $\mathrm{SN}$ was assessed after SN was added to freshly inoculated TSB or 2AS media at a 1:1 vol/vol ratio. Stored SNs were used immediately after thawing and were not refrozen and reused.

\section{Resuscitation of "Non-culturable" C. jeikeium Cells}

Non-culturable cells were separated from spent medium (centrifugation for $20 \mathrm{~min}$ at $5,000 \times \mathrm{g}$ ), that was serially diluted and used to inoculate either TSB or 2AS medium. An equal volume of either SN was prepared as indicated above, or appropriate uninoculated medium (control), and numbers of viable resuscitated cells were determined using the MPN assay (de Man, 1974).

\section{Sensitivity to Antibiotics and Heat Treatment}

Four milliliters of an early stationary phase (ESP) culture that was grown in TSB medium ( $\mathrm{pH} 7.0$ ) for 1 day or $4 \mathrm{~mL}$ of a 25 days old culture incubated at reduced $\mathrm{pH}$ were treated with 0 $10 \mu \mathrm{g}$ vancomycin/mL or $0-100 \mu \mathrm{g}$ rifampin/mL and incubated at $37^{\circ} \mathrm{C}$ or room temperature for $24 \mathrm{~h}$ without agitation. The number of resistant cells was determined using the MPN assay in the presence of TSB culture SN ( $5 \mathrm{~h}$, see above). One milliliter samples of ESP cultures or 25 days long incubated suspensions containing dormant cells were heated to $60,65,70,75$, or $80^{\circ} \mathrm{C}$ for $10 \mathrm{~min}$, and the number of survivors within samples were determined by evaluating the growth of bacteria in presence of SN (MPN assay).

\section{Pigment Extraction From the Cells}

Pigment was extracted from the biomass in accordance with the method described by Bligh and Dyer (Bligh and Dyer, 1959). First, $1 \mathrm{~mL}$ chloroform and $2 \mathrm{~mL}$ methanol were added to the wet biomass of cells $(0.8 \mathrm{~g})$. Cells were agitated for $12 \mathrm{~h}$ in the extraction mixture and subsequently centrifuged $(2,000 \times \mathrm{g})$, followed by the addition of $1 \mathrm{~mL}$ water and $1 \mathrm{~mL}$ chloroform (to separate phases). The chloroform layer was washed three times with $0.1 \mathrm{M} \mathrm{NaCl}$. The bacterial pellet was re-suspended in ice-cold $100 \mathrm{mM}$ HEPES (4-(2-hydroxyethyl)1-piperazineethanesulfonic acid) buffer ( $\mathrm{pH}$ 8.0) containing $2 \%$ Triton $\times 100$ (Sigma, United States) then lysed by using zirconium beads on a bead beater homogenizer (MP Biomedicals FastPrep-24) for $1 \mathrm{~min}$, five times and stayed in dark place at room temperature for $5 \mathrm{~h}$. The bacterial lysate was centrifuged at $13,000 \mathrm{rpm}$ for $15 \mathrm{~min}$ at $4^{\circ} \mathrm{C}$.

\section{Absorption and Fluorescence Spectra}

Absorption spectra were recorded on a Cary 300 Bio Spectrophotometer (Varian, Inc., United States). Fluorescence measurements were carried out with a Varian Cary Eclipse fluorimeter (Varian, Inc., United States).

\section{PDI}

Either dormant or active cell suspensions were used for lightinactivation experiments. C. jeikeium suspensions with OD values equal to 0.1 , which corresponded to approximately $10^{7}$ bacteria/mL, were used. Bacterial suspensions $(100 \mu \mathrm{L})$ were added to the wells of a Nunc 96-well plate (ThermoFisher Scientific, United States). Samples were illuminated with a SOLIS-4C light-emitting diode at $565 \mathrm{~nm}, 3.2 \mathrm{~W}$ using bandpass filter MF565-24 (Thorlabs, United States). The light beam was collimated to a diameter of $5 \mathrm{~mm}$, which corresponded to the diameter of the wells of the 96-well plate, and samples were illuminated for $60 \mathrm{~min}$. The power density of the light was 145 $\mathrm{mW}$ per well $\left(513 \mathrm{~mW} / \mathrm{cm}^{2}\right)$ as determined using a 2,936-c power meter (Newport, United States). Temperature was controlled an accuracy of $\pm 0.2^{\circ} \mathrm{C}$ by placing an $80 \mathrm{BK}$ type-K multimeter 
thermocouple (Fluke, Germany) directly in the microcell before and after lighting in the presence and absence of bacterial suspension. Temperatures were below $40^{\circ} \mathrm{C}$ in the wells of all samples. After the illumination of samples, numbers of viable bacteria were estimated using an MPN assay in presence of 5-h-old SN obtained from TSB medium (see above).

\section{Microscopy}

Cell suspensions were examined under a microscope (Eclipse E4000, Nikon, Japan) in phase-contrast and epifluorescence modes after staining with propidium iodide (PI) $(3 \mathrm{mM})$ to detect injured cells, ethidium bromide $(5 \mathrm{mM})$ to detect DNA-containing cells, or Nile red $(4 \mathrm{mg} / \mathrm{mL})$ to detect lipid inclusions. The excitation value was at $510 \mathrm{~nm}$ and emission was at $>560 \mathrm{~nm}$.

\section{Statistical Analysis}

Statistical processing was carried out using the analysis of the standard deviation or relative error within the data group. MPN values were determined using de Man's tables calculated on the base of Poisson distribution (de Man, 1974). For the MPN assay (95\%) confidence limits were calculated. The MPN values were considered statistically different if low and high confidence limits were not overlapped.

\section{RESULTS}

\section{Acidification of the Medium Induces Dormancy in in vitro Culture of C. jeikeium}

In order to modulate changes in $\mathrm{pH}$ values during the stationary phase of $C$. jeikeium culture we used developed by us a synthetic medium (2AS) supplemented with different glucose concentrations (0-40 g/L) (Figure 1). After a phase of modest alkalization (to approximately $\mathrm{pH} 6.8$ ), the gradual acidification of the culture to distinct final $\mathrm{pH}$ values were observed for glucose concentrations that ranged from 10 to $40 \mathrm{~g} / \mathrm{L}$. More significant $\mathrm{pH}$ decreases were observed in stationary phase cultures in 2AS medium containing 30-40 g/L glucose (Figure 1). In cultures grown with 10-20 g/L glucose, stationary phase of growth was established within approximately 3 days, and further incubation resulted in the gradual decrease of CFU values, starting about 4 days post-inoculation (Figure 2). A minimum CFU was found between 12 and 14 days after inoculation, which indicated that the cultures had transitioned to "non-culturability."

After the exponential growth, total cell counts (according to microscopy) and OD measurements were maintained at the constant level of $2.3 \pm 0.8 \times 10^{9}$ cells per $\mathrm{mL}$ for total count and $4.8 \pm 0.2$ for $\mathrm{OD}_{600}$. The exact time point at which culturability (according to CFU counts) demonstrated minimum values varied in different experiments. However, a correlation between culturability and culture acidification was evident (Figure 2).

Microscopic examination of non-culturable C. jeikeium grown at $10-20 \mathrm{~g} / \mathrm{L}$ glucose and stabilized at $\mathrm{pH} 5.5$ by adding $50 \mathrm{mM}$ MES (2-(N-morpholino)ethanesulfonic acid) buffer revealed that
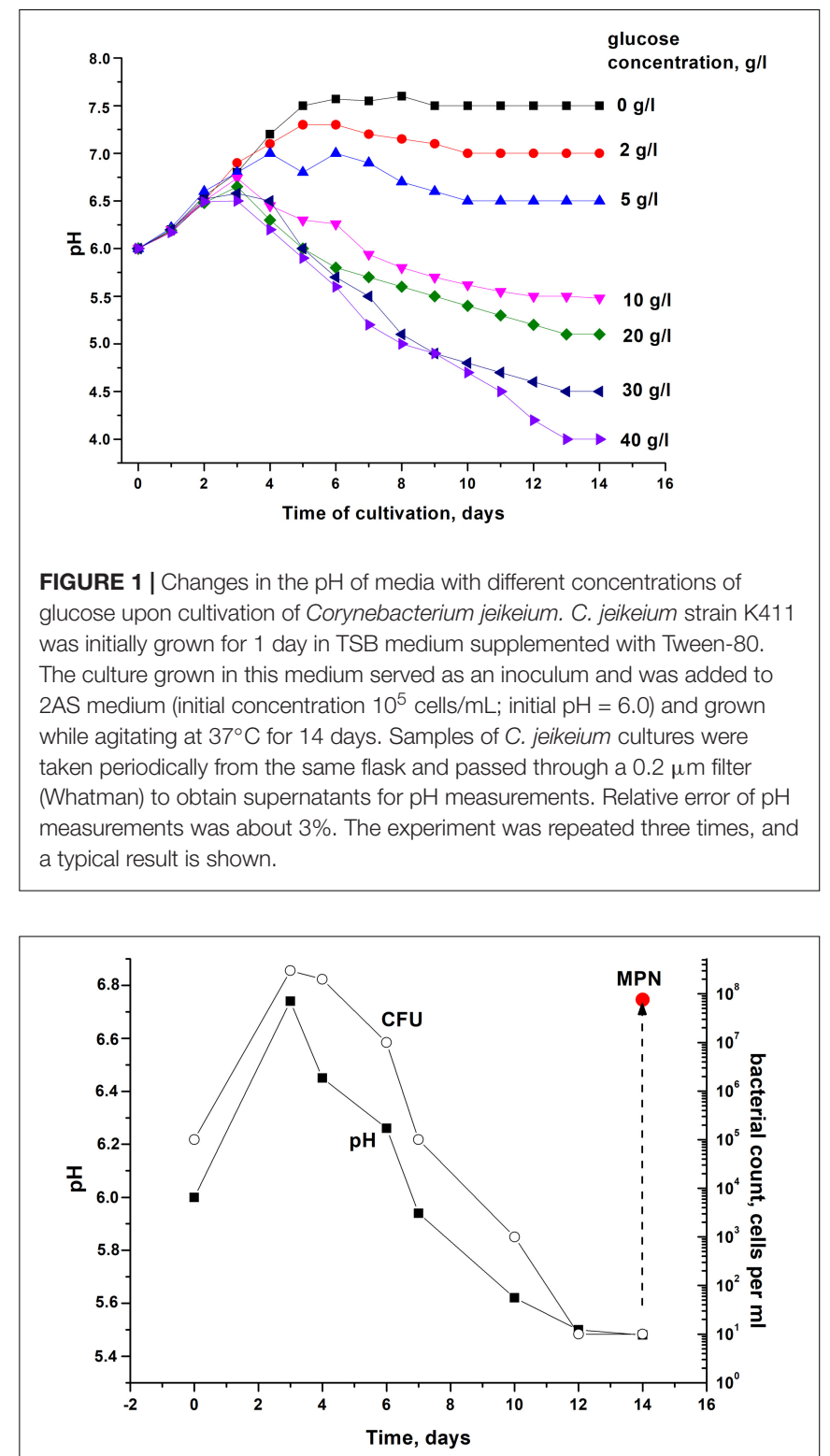

FIGURE 2 | Culturability of Corynebacterium jeikeium under medium levels of acidification in a prolonged stationary phase. C. jeikeium strain K411 was initially grown for 1 day in TSB medium supplemented with Tween-80. The culture grown in this medium served as an inoculum and was added to 2AS medium. Each inoculum ( $10^{5}$ cells per $\mathrm{ml}$ ) was added to flask with 2AS medium (initial pH6.0, $10 \mathrm{~g} / \mathrm{L}$ glucose) and grown while agitating at $37^{\circ} \mathrm{C}$ for 14 days. Samples of cultures were taken from flasks to determine $\mathrm{pH}, \mathrm{CFU}$, MPN and the CPM. MPN was estimated in the presence of supernatant taken from an actively growing $C$. jeikeium culture (see section "Materials and Methods"). Data shown are results of a typical experiment (five biological replicates). The relative error for CFU ranged between 10 and $30 \%$. The relative error of $\mathrm{pH}$ values was about $3 \%$. Bars represent (95\%) confidence limits for the MPN assay.

the majority of the cells displayed coccoid forms that were approximately $1 \pm 0.5 \mu \mathrm{m}$ in length. This was in contrast with characteristics of exponentially growing cells, which typically possess elongated ovoid shapes, are $2 \mu \mathrm{m}$ in length, and have an 


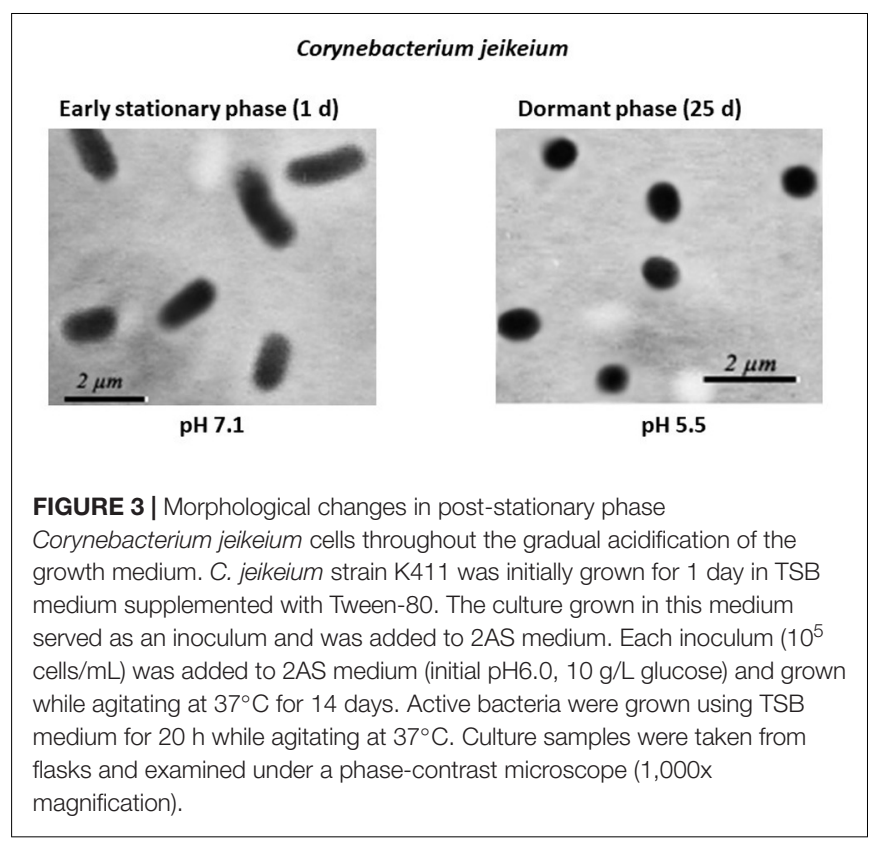

average diameter of $1 \mu \mathrm{m}$ (Figure 3). A microscopic assessment of dormant C. jeikeium cultures revealed that the majority of bacterial cells remained intact when incubated 30 days in liquid medium at room temperature, according to a PI test. When the cellular permeability barrier is destroyed, PI penetrates through cell wall and binds with DNA producing a fluorescent complex. According to this test $28 \pm 5 \%$ of PI-positively stained cells were found in stabilized dormant population vs. 5-10\% stained cells found in active cultures (Supplementary Figure 1). However, if the final $\mathrm{pH}$ value of the external environment was below 4.8, a significant number of dead bacteria appeared in the culture (Figure 1 and Table 1).

\section{Dormant C. jeikeium Cells Are Characterized by Low Metabolic Activity}

A metabolic activity assay was performed that estimated metabolic activity by evaluating levels of ${ }^{3} \mathrm{H}$-uracil incorporation. Cultures in which acidification was observed possessed significantly reduced levels of ${ }^{3} \mathrm{H}$-uracil incorporation relative to cultures in which $\mathrm{pH}$ values were maintained at neutral levels (Table 1). Under conditions where the maximum percentage of dormant intact cells was produced $(10-20 \mathrm{~g} / \mathrm{l}$ glucose, final $\mathrm{pH}$ 5.0-5.5), RNA synthesis activity was less than $1 \%$ of that for cells grown under neutral pH (Table 1).

\section{Resuscitation of Dormant C. jeikeium Cells}

The presence of ca. 90\% of PI-negative coccoid cells in C. jeikeium cultures in the post-stationary phase of growth in presence of $10 \mathrm{~g} / \mathrm{l}$ glucose (14 days) (Table 1) and ca. 70\% for 30 days old dormant cultures (Supplementary Figure 1) assumed that these morphologically changed cells (Figure 3) had kept their integrity and therefore potential viability, despite a sharp decrease in CFU number (Figure 2). Their potential viability was confirmed in resuscitation experiment via a MPN assay (Figure 2). After C. jeikeium cultures containing coccoid cells were incubated 1014 days after inoculation when CFU number had decreased up to zero, the number of viable cells estimated by MPN assay in liquid TSB medium reached $10^{5}$ cells $/ \mathrm{mL}$ (Figure $4 \mathrm{~A}$ ). Whilst the cultures further incubated for up to 5 months, the number of cells is able for resuscitation decreased up to undetectable level (Figure 4C). However, these cells could be resuscitated when supernatant obtained from replicating C. jeikeium was added to the resuscitation medium. Supernatant with maximum resuscitation activity was obtained from a growing in TSB medium for 5-12 h C. jeikeium cultures (Figures 4A,B). Samples stored as long as 5 months revealed concentration of potentially viable cells between $10^{7}$ and $10^{8}$ cells $/ \mathrm{mL}$ which could be resuscitated upon addition of SN (Figure 4C).

As revealed by microscopy, resuscitation of coccoid C. jeikeium cells resulted in their conversion to normal bacilli. According to $16 \mathrm{~S}$ RNA sequences coccoid C. jeikeium cells after resuscitation shown $100 \%$ identity to C. jeikeium.

\section{Dormant C. jeikeium Cells Are Resistant to Heat and Antibiotics}

According to MPN assays, coccoid cells from 25-days-old cultures were more resistant to heat treatment than exponentially growing cells (Figure 5A). As opposed to early stationaryphase cells, coccoid C. jeikeium cells were much more resistant to treatment with vancomycin $(0.5-10 \mu \mathrm{g} / \mathrm{mL}$ ) (Figure 5B) or rifampicin $(50-100 \mu \mathrm{g} / \mathrm{mL}$ ) (Figure 5C) for 1 day than early stationary phase cells, as revealed by MPN viability tests in presence of SN.

\section{Accumulation of Porphyrins by Dormant C. jeikeium Cells}

We found that dormant $C$. jeikeium cells accumulate a pigment characterized by the typical absorption spectra for porphyrins (Soret band at $400 \mathrm{~nm}$ and by emission maxima of fluorescence in the range of 620-670 nm) (Figures 6A,B). The intracellular

TABLE 1 | Medium pH, metabolic activity and percentage of dead cells in 14 days old C jeikeium cultures growns in 2AS medium supplemented by different glucose.

\begin{tabular}{|c|c|c|c|c|c|c|c|}
\hline Glucose concentration g/l & 0 & 2 & 5 & 10 & 20 & 30 & 40 \\
\hline \multicolumn{8}{|l|}{ Parameter } \\
\hline Medium pH & 7.5 & 7.0 & 6.5 & 5.48 & 5.1 & 4.5 & 4.0 \\
\hline \% dead bacterials cells $(\mathrm{PI}+)$ & $5 \pm 3$ & $4 \pm 2$ & $7 \pm 4$ & $10 \pm 2$ & $15 \pm 5$ & $40 \pm 8$ & $90 \pm 5$ \\
\hline Incorporation of $\mathrm{H}^{3}$-uracil $\mathrm{CPM} / \mathrm{mg}$ wet cell weight & $7,512 \pm 354$ & $7,244 \pm 265$ & $5,325 \pm 254$ & $62.7 \pm 22$ & $50.5 \pm 18$ & $20.2 \pm 5$ & $18.4 \pm 4.5$ \\
\hline
\end{tabular}

The mean $\pm S D$ is shown. 


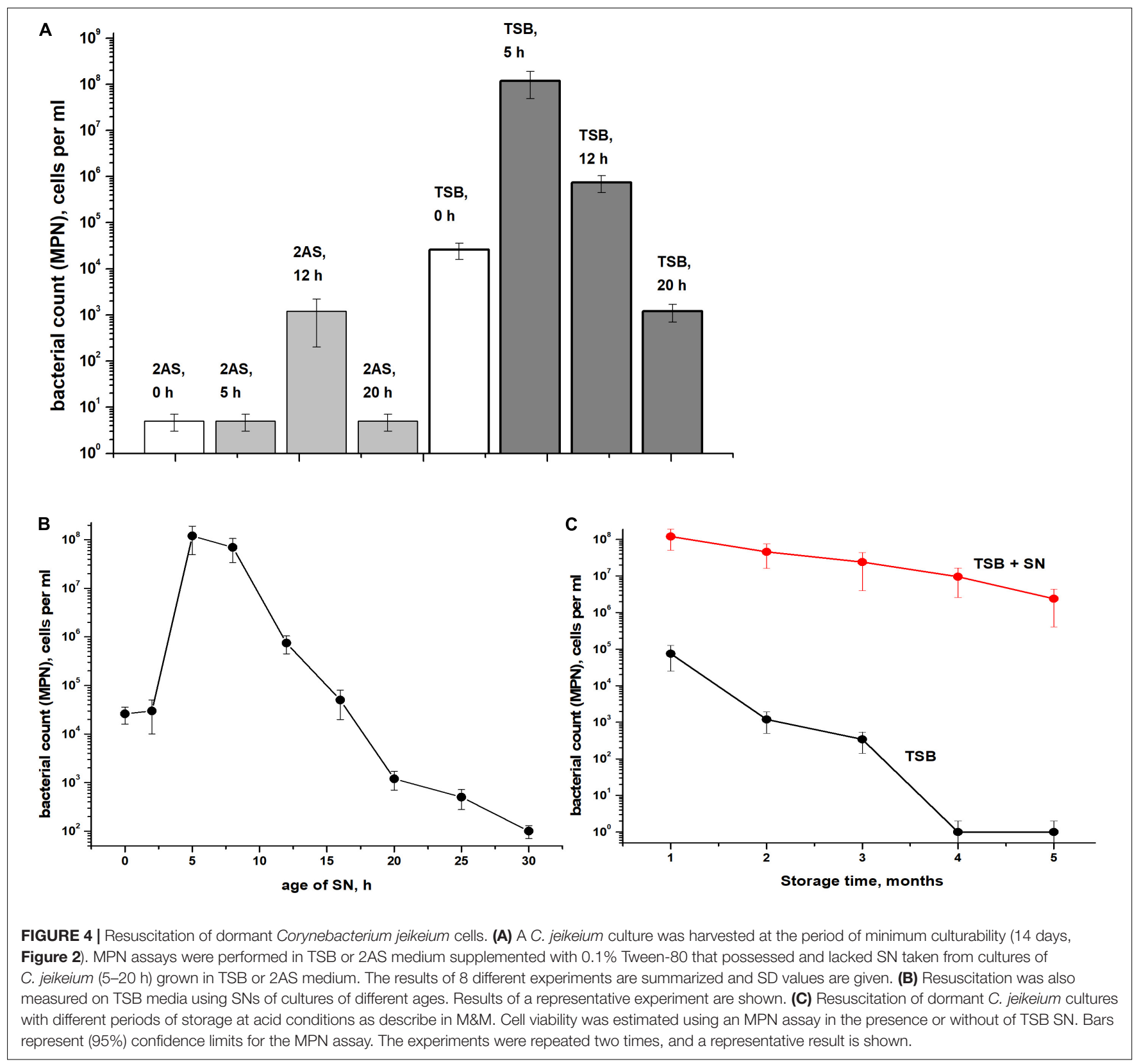

pigment concentration had the potential be increased if a precursor of porphyrin synthesis, 5-aminolevulinic acid (ALA) was added to the growth medium in accordance with spectral values produced by chloroform-methanol or Triton X100 extracts of dormant bacteria (Figure 6A).

\section{Photoinactivation of Dormant C. jeikeium Cells}

The effect providing $565 \mathrm{~nm}$ wavelength light (which coincides with the absorption of porphyrins in the visible region) on the viability of active and dormant corynebacterial forms grown in the presence and absence of $1.0 \mathrm{mM}$ ALA was studied (Figure 7A). The greatest decrease in the corynebacterial survival rate was observed when light was applied to dormant $C$. jeikeium formed in the presence of ALA in which a 4.5-log10 decrease in survival after 60 min of illumination was observed (Figure 7A). In case of cells taken from the early stationary growth phase $(20 \mathrm{~h})$, illumination did not reduce survival (MPN), but in presence of ALA photosensitivity increased (a 3-log10 decreased in viability was observed after illumination) (Figure 7A).

Microscopy was used to demonstrate that the illumination immediately resulted in the appearance of injured cells (Figure 7B). After 60 minutes of light exposure, about $68 \pm 5 \%$ of the dormant $C$. jeikeium cells formed in the medium contained ALA were damaged. In contrast, only $18 \pm 4 \%$ of unilluminated cells were damaged. $24 \mathrm{~h}$ later, this proportion of damaged cells in the population was greater than $99 \%$ (Figure 7B). 

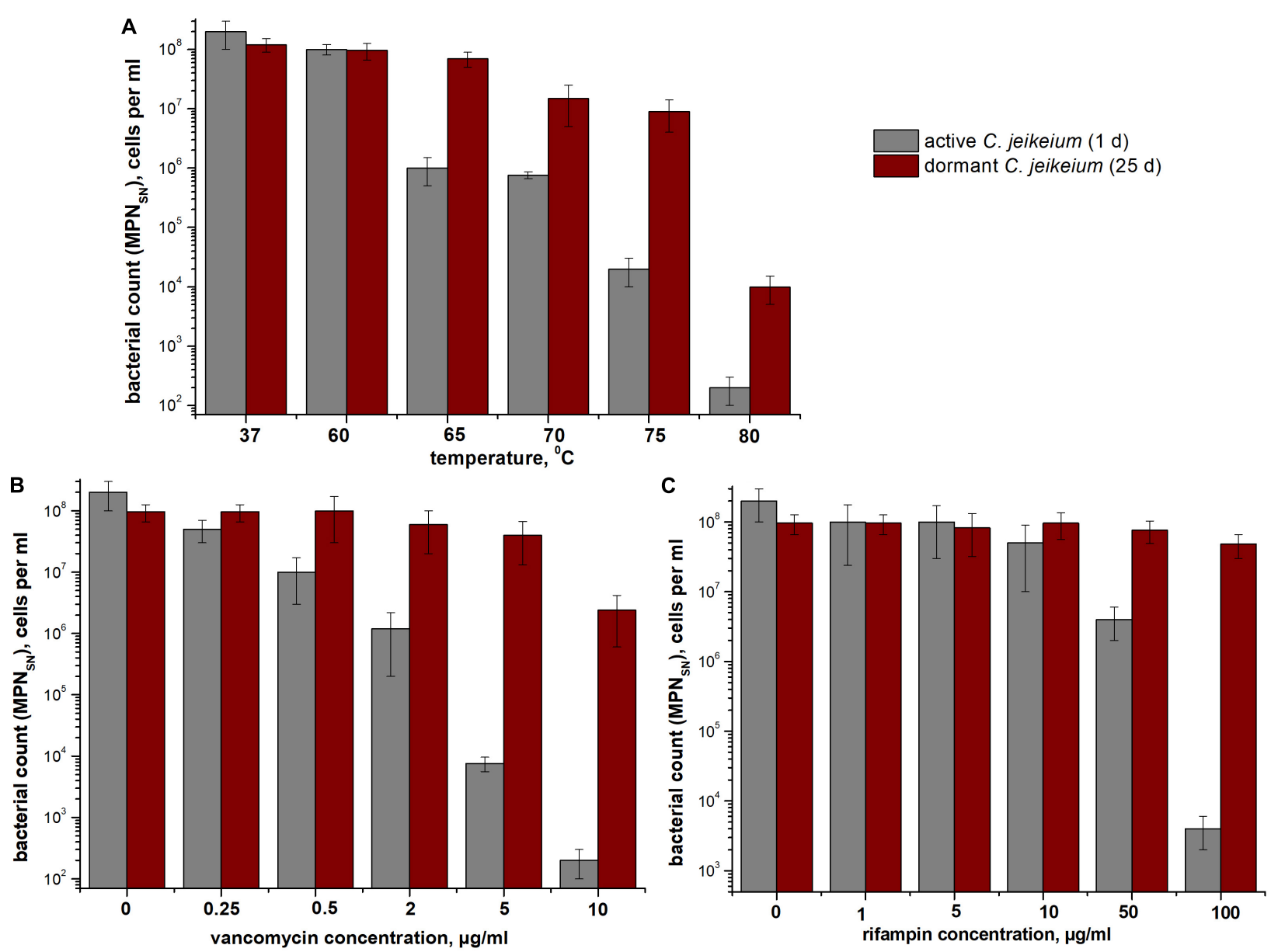

FIGURE $\mathbf{5}$ | Bacterial resistance to (A) high temperatures and (B,C) antibiotics. The sensitivity of Corynebacterium jeikeium cells to heating or antibiotic treatment is shown. Samples were taken from 25 days cultures that contained coccoid cells. For comparison, C. jeikeium cells were cultivated in TSB medium for 20 h (active cultures). Both types of cells were heated to $60-80^{\circ} \mathrm{C}$ for $10 \mathrm{~min}(\mathbf{A})$, treated with $0-10 \mu \mathrm{g}$ vancomycin/mL (B), or treated with 0-100 $\mu \mathrm{g}$ rifampin (C) and incubated at $37^{\circ} \mathrm{C}$ or room temperature for $24 \mathrm{~h}$ without agitation. Cell viability was estimated using an MPN assay in the presence of SN taken from culture grown in TSB medium for $5 \mathrm{~h}$ (for details see section "Materials and Methods"). Active cells are shown using gray columns and dormant cells are indicated using red columns. Bars represent (95\%) confidence limits for the MPN assay. The experiments were repeated three times, and a representative result is shown.

\section{DISCUSSION}

In this study, we ascribe conditions needed for corynebacterial cells to transition to a state of dormancy, which was accompanied by: (1) the formation of stress-resistant forms intended for longterm survival that have been identified in many spore-forming and non-spore-forming bacteria (Zhang, 2004; Mulyukin et al., 2010, 2014; Lennon and Jones, 2011) and (2) the acquisition of an NC state during the prolonged incubation of post-stationary cultures, which was previously described for Micrococcus luteus (Kaprelyants and Kell, 1993), Rhodococcus rhodochrous (Shleeva et al., 2002) and mycobacteria (M. tuberculosis and M. smegmatis) (Shleeva et al., 2003, 2004, 2011, 2015; Kudykina et al., 2011). The dormant forms of mycobacteria, which form when the external medium undergoes gradual acidification, can be distinguished from active bacteria based on their distinct proteomic (Trutneva et al., 2018, 2020) and metabolomic (Nikitushkin et al., 2020) profiles.
C. jeikeium cells formed in post-stationary cultures should be classified as dormant bacterial forms based on the following features: (i) the retention of viability throughout an extended incubation period (up to 5 months) (Figure 4), (ii) their low level of metabolism (Table 1), (iii) their enhanced resistance to deleterious factors such as high temperatures and antibiotic treatment (Figure 5), (iv) the acquisition of an NC state. In the NC state, cells maintain viability (the potential for proliferative activity), but could not produce colonies on agar media and, therefore, are not detected using standard tests (Colwell and Grimes, 2000; Oliver, 2010). The determination of whether non-sporulating $C$. jeikeium have the ability to transition to a long-lived dormant form of the bacteria has the potential to broaden our understanding of the mechanisms by which bacteria survive in natural systems when they encounter conditions not conducive for growth.

The NC state can be reversed by applying a resuscitation procedure in MPN assay either in fresh medium or in the 

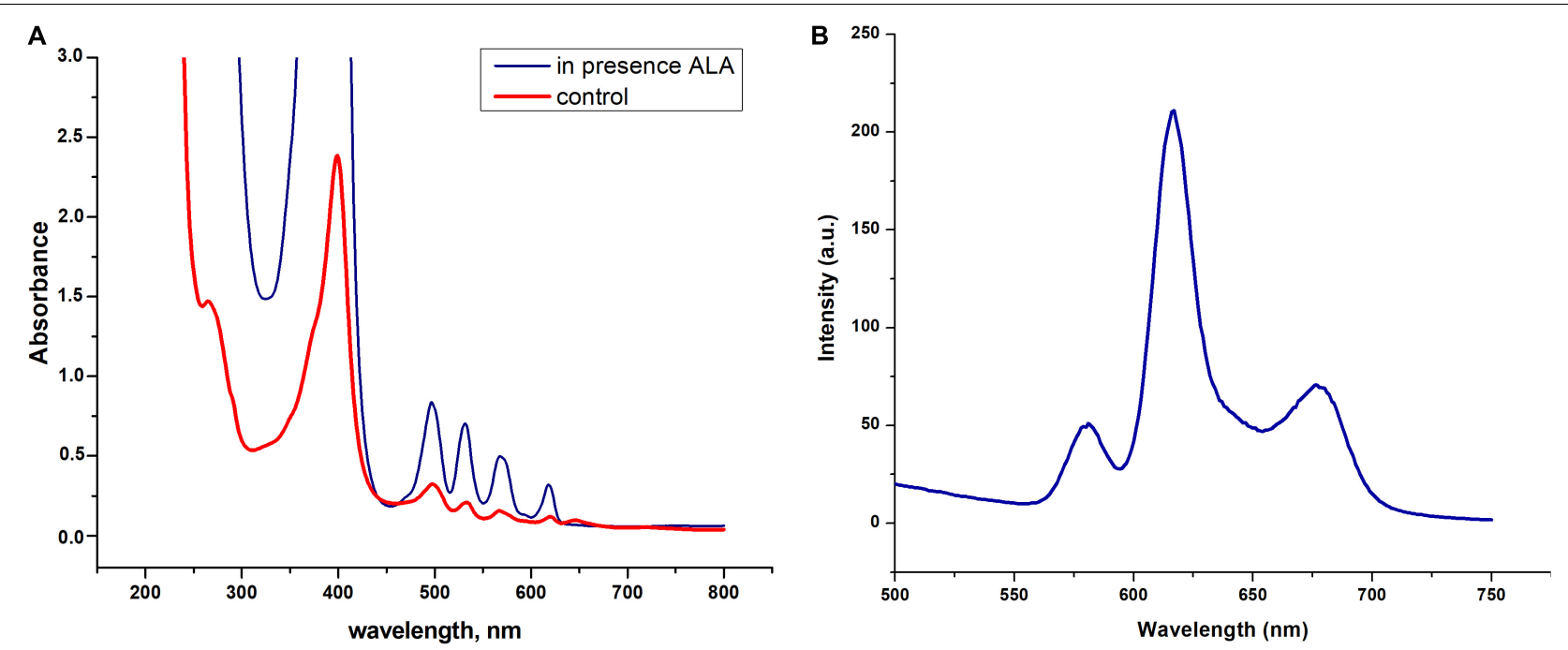

FIGURE 6 | Spectral properties dormant Corynebacterium jeikeium pigments. (A) Absorption spectra of a Triton X100 C. jeikeium extracts obtained from $0.8 \mathrm{~g}$ (wet weight) of cells for both cultures. The blue line indicates absorption spectrum of the extract from dormant bacteria grown in presence of 5-aminolevulinic acid. The red line indicates absorption spectrum of the Triton x 100 cellular extract from dormant bacteria grown without ALA (for details see section "Materials and Methods"). (B) Typical fluorescence emission spectra of extracted pigments ( $\lambda$ excitation, $400 \mathrm{~nm}$ ).

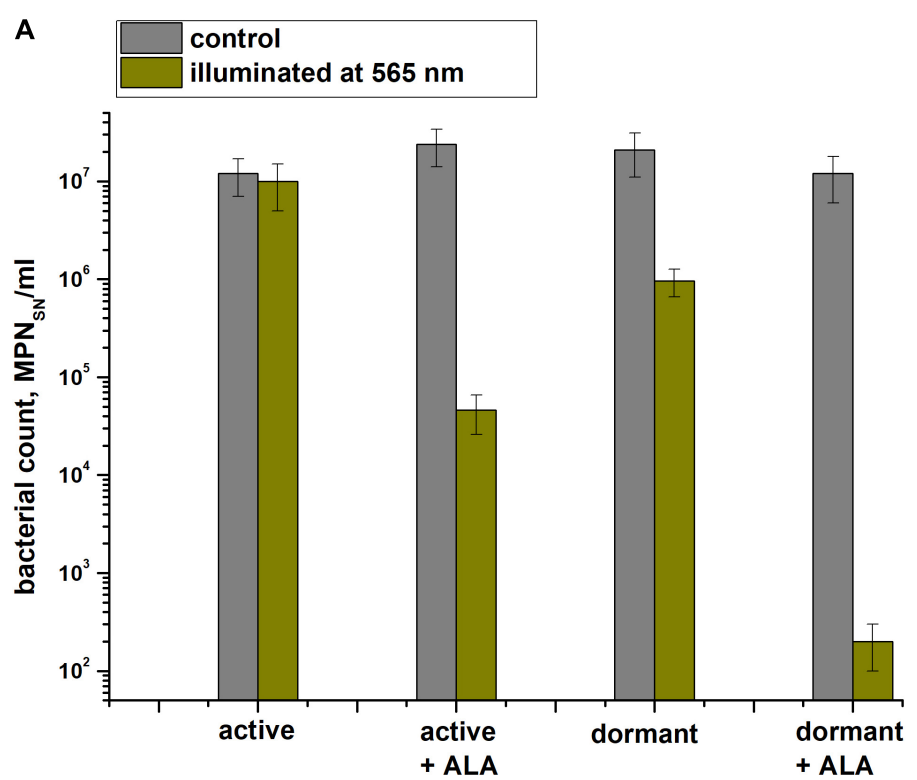

\section{B}

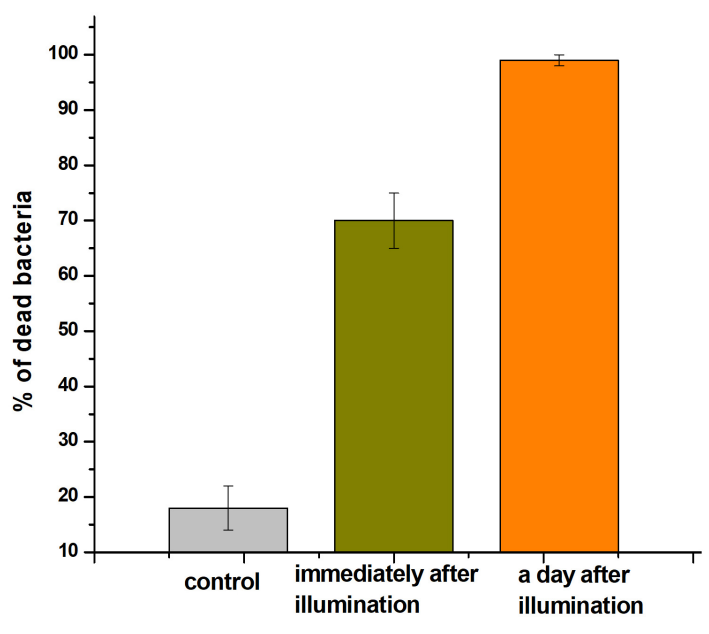

FIGURE 7 | Photodynamic inactivation of dormant Corynebacterium jeikeium at $565 \mathrm{~nm}$. Dormant and active cells in the presence or absence of ALA were obtained and subjected to PDI as described in section "Materials and Methods." (A) After 60 min of exposure under static conditions, numbers of viable bacteria were estimated via an MPN assay using 5-h-old SN of TSB cultures. Bars represent (95\%) confidence limits for the MPN assay. (B) Percentage of damaged dormant C. jeikeium cells estimated by PI staining microscopically immediately after illumination and $24 \mathrm{~h}$ later is shown. Bars represent \pm SD. Controls are unilluminated cells. The experiments were repeated three times, and a representative result is shown.

presence of SN. MPN assay was used to evaluate a number of potentially viable cells in cultures that were diluted to disappearance in liquid medium. At the same time this approach permitted the resuscitation of cells that were deprived of the ability to produce colonies on agar plates. This procedure was previously developed to resuscitate mycobacteria by cultivating "non-culturable" cells in liquid medium (Shleeva et al., 2011).
The increased necessity of $\mathrm{SN}$-based resuscitation as C. jeikeium cultures age could be due to the existence of cells in different physiological state: those that are simply unable to form colonies on plates and those that are at the depth of dormancy. Previously, we have found that a secreted protein Rpf (resuscitation promoting factor) provided culture SN activity for Micrococcus luteus (Mukamolova et al., 1998). The protein 
stimulates the resuscitation of non-culturable cells and shortens the lag phase of active $M$. luteus cultures inoculated with a low dose of bacteria. Rpf family is comprised of peptidoglycan hydrolases (Kana and Mizrahi, 2010) and the products of their enzymatic activity stimulate the reactivation of dormant mycobacteria (Nikitushkin et al., 2013, 2015). The expression of the rpfA gene in $M$. tuberculosis is under control of the transcriptional regulator Rv3676 and a cAMP receptor protein (CRP) (Rickman et al., 2005). Presumably, a protein similar to the Rpf protein in M. luteus is the active factor present within the cell free $C$. jeikeium culture liquid. Indeed, the C. jeikeium genome contains three genes encoding proteins similar to Rpf (JK_RS02150/jk0416, RpfA; JK_RS07760/jk1512, RpfB; JK_RS00265/jk0051, RpfC), which may be released into the environment and function to resuscitate NC C. jeikeium cells.

However, other reactivation stimulants, such as phospholipids (Zhang et al., 2001), free unsaturated fatty acids (Nazarova et al., 2011), cAMP (Shleeva et al., 2013), muropeptides (Nikitushkin et al., 2013), may also be present within the supernatant of actively growing bacterial cultures. It was previously shown that unsaturated fatty acid-dependent adenylate cyclase Rv2212 and a cAMP-dependent transcription factor of the Crp family Rv3676 participate in the reactivation of dormant forms of M. tuberculosis (Shleeva et al., 2017, 2019a). There is also a link between the Crp factor Rv3676 and RpfA protein synthesis (Bai et al., 2005). The C. jeikeium genome contains a gene encoding a cAMP-dependent transcriptional regulator of Crp family, glxR (JK_RS10065/jk1972), which may have a function that is similar to Rv3676.

It is clear that dormant cells could be of significant importance for medicine and microbiology due to their ability to form normal, viable organisms after resuscitation (Kaprelyants et al., 1993; Barer, 1997; Barer et al., 1998; Kell et al., 1998; Barer and Harwood, 1999; Mukamolova et al., 2003). For example, diphtheria bacteriocarrier phenomenon is known, and is considered one of the mechanisms by which a pathogen can persist within the host organism (Deviatova, 1956; DeWinter et al., 2005; Kostyukova and Bechalo, 2018).

C. jeikeium cells are resistant to a number of many betalactam antibiotics, doxycycline and ciprofloxacin, but they are sensitive to vancomycin and rifampicin (Soriano et al., 1995). However, the dormant forms of $C$. jeikeium used in the study that were produced as a result of the acidification of the environment proved to be resistant to both rifampicin and vancomycin (Figures 4B,C). Researchers previously demonstrated that, in some cases, vancomycin may be ineffective in the treatment of C. jeikeium bacteremia and endocarditis and disease recurrence occurred despite providing an extended course of antimicrobial therapy (Vanbosterhaut et al., 1989; Clarke et al., 2019). Wang et al. (2001) "retrospectively reviewed 53 cases of C. jeikeium bacteremia in bone marrow transplant recipients who had a Hickman catheter without signs of local catheter site infection. The results showed that salvage of catheter with vancomycin therapy is successful in most patients (93\%)" (Bookani et al., 2018). However, $7 \%$ of patients that underwent catheter salvage were affected by recurrent bacteremia. Whilst the genetic characterization of causative pathogen was not performed in the study, the emergence of such resistance of corynebacteria to the antibiotic could be a consequence of the transition of bacteria to a dormant state, which protects them from being killed by antibiotic treatment. The fact that C. jeikeium was resistant to both vancomycin and rifampicin allows us to suggest a model of C. jeikeium dormancy that can be used to screen for new drugs that possess activity against chronic C. jeikeium bacteremia.

Evidently, dormant bacteria with little metabolic activity are capable of avoiding effects of antibiotics even though they remain suitable targets. It can be assumed that the effect of complete elimination of dormant, "non-culturable" bacteria can be accomplished by factors which produce indirect, harmful effects on bacteria (Kaprelyants et al., 2018). In this regard, we employed a previously discovered phenomenon of the accumulation of free and methylated porphyrins in dormant mycobacteria (Nikitushkin et al., 2016). This finding made it possible to induce the PDI of mycobacteria (Shleeva et al., 2019b, 2020). In the present study we found that dormant C. jekeium cells accumulate a pigment which according to the spectral properties (Figures 6A,B) evidently belong to a class of porphyrins (Gouterman, 1961).

Of the currently available photosensitizers (PSs) available, porphyrin and its analogs have the following advantages: (1) many are effective producers of singlet oxygen; (2) they usually do not generate singlet oxygen in the absence of light; (3) they absorb in the red region of the optical spectrum; and (4) they are relatively stable. As an alternative to antibiotic treatment for killing dormant C. jeikeium, PDI was a promising approach that was used for killing dormant bacteria (Figure 7). In a previous study, an elevated accumulation of coproporphyrin III was observed in C. diphtheriae culture filtrates (Gray, 1948). The overproduction of porphyrins was also observed in 15 days old $C$. acnes cultures (Cornelius and Ludwig, 1967). However, the link between porphyrin accumulation and C. jeikeium dormancy was not established previously.

The functional role for the porphyrins that accumulate in dormant bacteria is not clear. Likely that newly found, hydrophobic porphyrins may stabilize and protect dormant cells against unfavorable conditions or destructive factors (Patel and Day, 1999; Castello et al., 2008; Antonova et al., 2010). In addition, stored porphyrins may be utilized as metabolites in biochemical pathways during dormant bacterial cell reactivation.

Bacterial killing in association with PDI seems to be due to the production of reactive oxygen compounds, which participate in the oxidation of such important molecules as enzymes, proteins, lipids and nucleic acids, are lethal to the bacterial cell (Demidova and Hamblin, 2004; Jori et al., 2006). PDI is known as a robust approach for killing bacterial cell including multi-resistant bacteria (Grinholc et al., 2008; Cassidy et al., 2010). PDI was found to be efficient for eliminating of a number of bacteria (Plavskii et al., 2018), including virulent E.coli O157H7, Listeria monocytogenes (Romanova et al., 2003), Neisseria gonorrhoeae (Wang et al., 2019) and Legionella rubrilucens (Schmid et al., 2019). Commonly, exogenously added photosensitizers, in particular porphyrins, were applied in PDI experiments (Liu et al., 2015; Guterres et al., 2020; Rossi et al., 2020). For example, cyclodextrin with bound porphyrins has been applied 
for the treatment of Staphylococcus aureus (Hanakova et al., 2014). Endogenous porphyrins were utilized for the killing of pathogenic periodontal bacteria (Cieplik et al., 2014; Hope et al., 2016), skin pathogens St. aureus (Ashkenazi et al., 2003; Lipovsky et al., 2009), Staphylococcus carnosus (Hoenes et al., 2020), Hemophilis parainfluenzae (van der Meulen et al., 1997) and Helicobacter pylori (Hamblin et al., 2005; Morici et al., 2020).

Apart of photosensitizer, application of 5-aminolevulinic acid (ALA) was employed as another approach. ALA being photodynamically inactive stimulates biosynthesis of endogenous PSs in cells that enhances harmful effect upon illumination (Harris and Pierpoint, 2008; Bohm et al., 2020). In bacteria, close to eukaryotic cells, the biosynthesis of porphyrins from ALA took place, and ALA administrated to the cell culture enhances porphyrin accumulation in the cell (Nitzan et al., 2004).

Application of ALA-PDI in clinic revealed positive results notably for the skin diseases such as acne, chronic folliculitis, rosacea, lichen sclerosis and skin lesions caused by Mycobacterium marinum. According to the clinical trials, the usage of ALA-PDI look promising for the treatment of ulcers caused by Helicobacter pylori (Wilder-Smith et al., 2002; Nitzan et al., 2004). However, the application of PDI for eliminating both active and dormant corynebacteria was demonstrated for the first time in the present study. This work suggested a new approach that has the potential to be used to eradicate dormant corynebacteria in clinical settings.

\section{CONCLUSION}

Under gradual medium acidification, C. jeikeium cells transit to dormant "non-culturable" state with the retention of viability, low level of metabolism, enhanced resistance to deleterious factors, porphyrins overproduction. This model of C. jeikeium dormancy can be used to screen for new drugs that possess activity against persisting $C$. jeikeium. Resistant to antibiotics dormant $C$. jeikeium cells can be eliminated by application of photodynamic inactivation due to the endogenous porphyrin

\section{REFERENCES}

Antonova, N. A., Osipova, V. P., Kolyada, M. N., Movchan, N. O., Milaeva, E. R., and Pimenov, Y. T. (2010). Study of the antioxidant properties of porphyrins and their complexes with metals. Macroheterocycles 3, 139-144. doi: 10.6060/ mhc2010.2-3.139

Ashkenazi, H., Malik, Z., Harth, Y., and Nitzan, Y. (2003). Eradication of Propionibacterium acnes by its endogenic porphyrins after illumination with high intensity blue light. FEMS Immunol. Med. Microbiol. 35, 17-24. doi: 10. 1016/S0928-8244(02)00423-6

Bai, G., Mccue, L. A., and Mcdonough, K. A. (2005). Characterization of Mycobacterium tuberculosis Rv3676 (CRP Mt), a cyclic AMP receptor proteinlike DNA binding protein. J. Bacteriol. 187, 7795-7804. doi: 10.1128/JB.187.22. 7795

Barer, M. R. (1997). Viable but non-culturable and dormant bacteria: time to resolve an oxymoron and a misnomer? J. Med. Microbiol. 46, 629-631. doi: 10.1099/00222615-46-8-629

Barer, M. R., and Harwood, C. R. (1999). Bacterial viability and culturability. $A d v$. Microb. Physiol. 41, 93-137. doi: 10.1016/s0065-2911(08)60166-6

Barer, M. R., Kaprelyants, A. S., Weichart, D. H., Harwood, C. R., and Kell, D. B. (1998). Microbial stress and culturability: conceptual and operational accumulation. The stimulation of porphyrin production by ALA in dormant and active corynebacteria enhances their sensitivity to photodynamic inactivation.

\section{DATA AVAILABILITY STATEMENT}

The original contributions presented in the study are included in the article/Supplementary Material, further inquiries can be directed to the corresponding author/s.

\section{AUTHOR CONTRIBUTIONS}

AK and MS conceived, designed the experiments, wrote the manuscript, and revised the manuscript. MS and AS performed the experiments. AK, AS, and MS analyzed the data. MS prepared figures and graphs. All the authors read and approved the final manuscript.

\section{FUNDING}

This study was funded by Russian Science Foundation grant 1915-00324 (studies of PDI) and the Russian Ministry of Science and Higher Education (formation of dormant corynebacteria).

\section{SUPPLEMENTARY MATERIAL}

The Supplementary Material for this article can be found online at: https://www.frontiersin.org/articles/10.3389/fmicb. 2020.605899/full\#supplementary-material

Supplementary Figure 1 | Percentage of damaged C. jeikeium cells. Dormant and active cells were obtained as described in section "Materials and Methods." Proportion of dead cells was estimated microscopically by counting propidium iodide (PI)-negative cells in a Helber's chamber. Bars represent $\pm \mathrm{SD}$. The experiments were repeated two times, and a representative result is shown.

domains. Microbiology 144, 2009-2010. doi: 10.1099/00221287-144-82009

Bernard, K. (2012). The genus Corynebacterium and other medically relevant coryneform-like bacteria. J. Clin. Microbiol. 50, 3152-3158. doi: 10.1128/JCM. 00796- 12

Biketov, S., Mukamolova, G. V., Potapov, V., Gilenkov, E., Vostroknutova, G., Kell, D. B., et al. (2000). Culturability of Mycobacterium tuberculosis cells isolated from murine macrophages: a bacterial growth factor promotes recovery. FEMS Immunol. Med. Microbiol. 29, 233-240. doi: 10.1016/S0928-8244(00) 00210-8

Bligh, E., and Dyer, W. J. (1959). A rapid method of total lipid extraction and purification. Can. J. Biochem. Physiol. 37, 911-917.

Blokpoel, M. C. J., Murphy, H. N., O’Toole, R., Wiles, S., Runn, E. S. C., Stewart, G. R., et al. (2005). Tetracycline-inducible gene regulation in Mycobacteria. Nucleic Acids Res. 33:e22. doi: 10.1093/nar/gni023

Bohm, G. C., Gándara, L., Di, V. G., Mamone, L., Buzzola, F., and Casas, A. (2020). Photodynamic inactivation mediated by 5 -aminolevulinic acid of bacteria in planktonic and biofilm forms. Biochem. Pharmacol. 177:114016. doi: 10.1016/ j.bcp.2020.114016

Bookani, K. R., Marcus, R., Cheikh, E., Parish, M., and Salahuddin, U. (2018). Corynebacterium jeikeium endocarditis: a case report and comprehensive 
review of an underestimated infection. IDCases 11, 26-30. doi: 10.1016/j.idcr. 2017.11.004

BoseDasgupta, S., and Pieters, J. (2018). Macrophage-microbe interaction: lessons learned from the pathogen Mycobacterium tuberculosis. Semin. Immunopathol. 40, 577-591. doi: 10.1007/s00281-018-0710-0

Cassidy, C. M., Donnelly, R. F., and Tunney, M. M. (2010). Effect of sub-lethal challenge with photodynamic antimicrobial chemotherapy (PACT) on the antibiotic susceptibility of clinical bacterial isolates. J. Photochem. Photobiol. B Biol. 99, 62-66. doi: 10.1016/j.jphotobiol.2010.02.004

Castello, P., Drechsel, D. A., Day, B. J., and Patel, M. (2008). Inhibition of mitochondrial hydrogen peroxide production by lipophilic metalloporphyrins. J. Pharmacol. Exp. Ther. 324, 970-976. doi: 10.1124/jpet.107.132134

Cellini, L., Marzio, L., Allocati, N., Dainelli, B., Lezzi, T., Angelucci, D., et al. (1994). Coccoid Helicobacter pylori not culturable in vitro reverts in mice. Microbiol. Immunol. 38, 843-850. doi: 10.1111/j.1348-0421.1994.tb02136.x

Chambers, H. F., and Deleo, F. R. (2009). Waves of resistance: Staphylococcus aureus in the antibiotic era. Nat. Rev. Microbiol. 7, 629-641. doi: 10.1038/ nrmicro2200.Waves

Cieplik, F., Späth, A., Leibl, C., Gollmer, A., Regensburger, J., Tabenski, L., et al. (2014). Blue light kills Aggregatibacter actinomycetemcomitans due to its endogenous photosensitizers. Clin. Oral Investig. 18, 1763-1769. doi: 10.1007/ s00784-013-1151-8

Clarke, J. R. D., Abdur Rahman, M., and Saul, Z. (2019). A case of recurrent Corynebacterium jeikeium endocarditis: unanswered questions for the treatment of chronic endovascular infections. IDCases 18:e0610. doi: 10.1016/ j.idcr.2019.e00610

Colwell, R. R., and Grimes, D. R. (2000). Non-Culturable Microorganisms in the Environments. Washington, DC: ASM Press.

Cornelius, C. III, and Ludwig, G. (1967). Red fluorescence of comedones: production of porphyrins by Corynebacterium acnes. J. Invest. Dermatol. 49, 368-370. doi: 10.1038/jid.1967.150

Currás, M., Magariños, B., Toranzo, A. E., and Romalde, J. L. (2002). Dormancy as a survival strategy of the fish pathogen Streptococcus parauberis in the marine environment. Dis. Aquat. Organ. 52, 129-136. doi: 10.3354/dao052129

de Man, J. C. (1974). The probability of most probable numbers. Eur. J. Appl. Microbiol. 1, 67-78. doi: 10.1007/BF01880621

Demidova, T. N., and Hamblin, M. R. (2004). Photodynamic therapy targeted to pathogens. Int. J. Immunopathol. Pharmacol. 17, 245-254. doi: 10.1177/ 039463200401700304

Deretic, V., and Fratti, R. A. (1999). Mycobacterium tuberculosis phagosome. Mol. Microbiol. 31, 1603-1609. doi: 10.1046/j.1365-2958.1999.01279.x

Deviatova, L. (1956). K voprosu o lechenii nositelei difteriinykh palochek [Problem of the treatment of carriage of Corynebacterium diphtheriae]. Zh. Mikrobiol. Epidemiol. Immunobiol. 27, 39-42. doi: 10.1007/978-94-007-7624-1_3

DeWinter, L. M., Bernard, K. A., and Romney, M. G. (2005). Human clinical isolates of Corynebacterium diphtheriae and Corynebacterium ulcerans collected in Canada from 1999 to 2003 but not fitting reporting criteria for cases of diphtheria. J. Clin. Microbiol. 43, 3447-3449. doi: 10.1128/JCM.43.7.3447-3449. 2005

El-Registan, G. I., Mulyukin, A. L., Nikolaev, Y. A., Suzina, N. E., Gal'chenko, V. F., and Duda, V. I. (2006). Adaptogenic functions of extracellular autoregulators of microorganisms. Microbiology 75, 380-389. doi: 10.1134/S0026261706040035

Funke, G., Von Graevenitz, A., Clarridge, J. E., and Bernard, K. A. (1997). Clinical microbiology of Coryneform bacteria. Clin. Microbiol. Rev 10, 125-159. doi: $10.1128 / \mathrm{cmr} .10 .1 .125$

Gouterman, M. (1961). Spectra of porphyrins. J. Mol. Spectrosc. 6, 138-163. doi: 10.1016/0370-2693(87)90819-7

Gray, C. H. (1948). The Isolation of coproporphyrin III from Corynebacterium diphtheriae. Biochem. J. 43, 191-193. doi: 10.1042/bj0430191

Grinholc, M., Szramka, B., Kurlenda, J., Graczyk, A., and Bielawski, K. P. (2008). Bactericidal effect of photodynamic inactivation against methicillinresistant and methicillin-susceptible Staphylococcus aureus is strain-dependent. J. Photochem. Photobiol. B Biol. 90, 57-63. doi: 10.1016/j.jphotobiol.2007. 11.002

Guterres, K. B., Rossi, G. G., de Campos, M. M. K. A., Moreira, K. S., Burgo, T. A. L., and Iglesias, B. A. (2020). Metal center ion effects on photoinactivating rapidly growing Mycobacteria using water-soluble tetra-cationic porphyrins. Biometals 33, 269-282. doi: 10.1007/s10534-020-00251-3
Hacker, E., Ott, L., Schulze-Luehrmann, J., Lührmann, A., Wiesmann, V., Wittenberg, T., et al. (2016). The killing of macrophages by Corynebacterium ulcerans. Virulence 7, 45-55. doi: 10.1080/21505594.2015.1125068

Hamblin, M. R., Viveiros, J., Yang, C., Ahmadi, A., Ganz, R. A., and Tolkoff, M. J. (2005). Helicobacter pylori accumulates photoactive porphyrins and is killed by visible light. Antimicrob. Agents Chemother. 49, 2822-2827. doi: 10.1128/AAC. 49.7.2822-2827.2005

Hanakova, A., Bogdanova, K., Tomankova, K., Pizova, K., Malohlava, J., Binder, S., et al. (2014). The application of antimicrobial photodynamic therapy on S. aureus and E. coli using porphyrin photosensitizers bound to cyclodextrin. Microbiol. Res. 169, 163-170. doi: 10.1016/j.micres.2013.07.005

Harris, F., and Pierpoint, L. (2008). Photodynamic therapy based on 5aminolevulinic acid and its use as an antimicrobial agent. Med. Res. Rev. 32, 1292-1327. doi: 10.1002/med

Hoenes, K., Wenzel, U., Spellerberg, B., and Hessling, M. (2020). Photoinactivation sensitivity of Staphylococcus carnosus to visible-light irradiation as a function of wavelength. Photochem. Photobiol. 96, 156-169. doi: 10.1111/php.13168

Hope, C. K., Strother, M., Creber, H. K., and Higham, S. M. (2016). Lethal photosensitisation of prevotellaceae under anaerobic conditions by their endogenous porphyrins. Photodiagn. Photodyn. Ther. 13, 344-346. doi: 10. 1016/j.pdpdt.2015.07.173

Ifantidou, A. M., Diamantidis, M. D., Tseliki, G., Angelou, A. S., Christidou, P., Papa, A., et al. (2010). Corynebacterium jeikeium bacteremia in a hemodialyzed patient. Int. J. Infect. Dis. 14, e265-e268. doi: 10.1016/j.ijid.2009.11.008

Jori, G., Fabris, C., Soncin, M., Ferro, S., Coppellotti, O., Dei, D., et al. (2006). Photodynamic therapy in the treatment of microbial infections: basic principles and perspective applications. Lasers Surg. Med. 38, 468-481. doi: 10.1002/1sm. 20361

Kana, B. D., and Mizrahi, V. (2010). Resuscitation-promoting factors as lytic enzymes for bacterial growth and signaling. FEMS Immunol. Med. Microbiol. 58, 39-50. doi: 10.1111/j.1574-695X.2009.00606.x

Kaprelyants, A., Gottschal, J., and Kell, D. (1993). Dormancy in non-sporulating bacteria. FEMS Microbiol. Rev. 104, 271-285. doi: 10.1111/j.1574-6968.1993. tb05871.x

Kaprelyants, A., and Kell, D. (1993). Dormancy in stationary-phase cultures of Micrococcus luteus: flow cytometric analysis of starvation and resuscitation. Appl. Environ. Microbiol. 59, 3187-3196. doi: 10.1128/aem.59.10.3187-3196. 1993

Kaprelyants, A., Salina, E., and Makarov, V. (2018). How to kill dormant Mycobacterium tuberculosis. Int. J. Mycobacteriol. 7, 399-400. doi: 10.4103/ ijmy.ijmy

Kell, D. B., Kaprelyants, A. S., Weichart, D. H., Harwood, C. R., and Barer, M. R. (1998). Viability and activity in readily culturable bacteria: a review and discussion of the practical issues. Antonie Van Leeuwenhoek Int. J. Gen. Mol. Microbiol. 73, 169-187. doi: 10.1023/A:1000664013047

Keren, I., Shah, D., Spoering, A., Kaldalu, N., and Lewis, K. (2004). Specialized persister cells and the mechanism of multidrug tolerance in Escherichia coli. J. Bacteriol. 186, 8172-8180. doi: 10.1128/JB.186.24.8172-8180.2004

Kostyukova, N. N., and Bechalo, Y. A. (2018). Diphtheria carriage. Epidemiol. Vaccin. Prev. 17, 60-70. doi: 10.31631/2073-3046-2018-17-5-60-70

Kudykina, Y. K., Shleeva, M. O., Artsabanov, V. Y., Suzina, N. E., and Kaprelyants, A. S. (2011). Generation of dormant forms by Mycobacterium smegmatis in the poststationary phase during gradual acidification of the medium. Microbiology 80, 638-649. doi: 10.1134/s0026261711050080

Lee, D. G., Park, S. J., and Kim, S. J. (2007). Influence of pipe materials and VBNC cells on culturable bacteria in a chlorinated drinking water model system. J. Microbiol. Biotechnol. 17, 1558-1562.

Lee, M., Hesek, D., Shah, I., Oliver, A., Dworkin, J., and Mobashery, S. (2010). Synthetic peptidoglycan motifs for germination of bacterial spores. Chembiochemistry 11, 2525-2529. doi: 10.1002/cbic.201000626.Synthetic

Lennon, J. T., and Jones, S. E. (2011). Microbial seed banks: the ecological and evolutionary implications of dormancy. Nat. Rev. Microbiol. 9, 119-130. doi: $10.1038 /$ nrmicro2504

Lewis, K. (2007). Persister cells, dormancy and infectious disease. Nat. Rev. Microbiol. 5, 48-56. doi: 10.1038/nrmicro1557

Lipovsky, A., Nitzan, Y., Friedmann, H., and Lubart, R. (2009). Sensitivity of Staphylococcus aureus strains to broadband visible light. Photochem. Photobiol. 85, 255-260. doi: 10.1111/j.1751-1097.2008.00429.x 
Liu, Y., Qin, R., Zaat, S. A. J., Breukink, E., and Heger, M. (2015). Antibacterial photodynamic therapy: overview of a promising approach to fight antibioticresistant bacterial infections. J. Clin. Transl. Res. 1, 140-167.

Mookadam, F., Cikes, M., Baddour, L. M., Tleyjeh, I. M., and Mookadam, M. (2006). Corynebacterium jeikeium endocarditis: a systematic overview spanning four decades. Eur. J. Clin. Microbiol. Infect. Dis. 25, 349-353. doi: 10.1007/ s10096-006-0145-8

Morici, P., Battisti, A., Tortora, G., Menciassi, A., Checcucci, G., Ghetti, F., et al. (2020). The in vitro Photoinactivation of Helicobacter pylori by a novel LED-based device. Front. Microbiol. 11:283. doi: 10.3389/fmicb.2020. 00283

Mukamolova, G., Kaprelyants, A., Kell, D., and Young, M. (2003). Adoption of the transiently non-culturable state - a bacterial survival strategy? Adv. Microb. Physiol. 47, 65-129. doi: 10.1016/s0065-2911(03)47002-1

Mukamolova, G. V., Kaprelyants, A. S., Young, D. I., Young, M., and Kell, D. B. (1998). A bacterial cytokine. Proc. Natl. Acad. Sci. U.S.A. 95, 8916-8921. doi: 10.1073/pnas.95.15.8916

Mulyukin, A. L., Kudykina, Y. K., Shleeva, M. O., Anuchin, A. M., Suzina, N. E., Danilevich, V. N., et al. (2010). Intraspecies diversity of dormant forms of Mycobacterium smegmatis. Microbiology 79, 461-471. doi: 10.1134/ S0026261710040089

Mulyukin, A. L., Suzina, N. E., Mel'nikov, V. G., Gal'chenko, V. F., and El'-Registan, G. I. (2014). Dormant state and phenotypic variability of Staphylococcus aureus and Corynebacterium pseudodiphtheriticum. Microbiology 83, 149-159. doi: 10. $1134 /$ S0026261713060088

Nazarova, E. V., Shleeva, M. O., Morozova, N. S., Kudykina, Y. K., Vostroknutova, G. N., Ruzhitsky, A. O., et al. (2011). Role of lipid components in formation and reactivation of Mycobacterium smegmatis "nonculturable" cells. Biochemistry 76, 636-644. doi: 10.1134/S0006297911060034

Nikitushkin, V. D., Demina, G. R., Shleeva, M. O., Guryanova, S. V., Ruggiero, A., Berisio, R., et al. (2015). A product of RpfB and RipA joint enzymatic action promotes the resuscitation of dormant Mycobacteria. FEBS J. 282, 2500-2511. doi: $10.1111 /$ febs.13292

Nikitushkin, V. D., Demina, G. R., Shleeva, M. O., and Kaprelyants, A. S. (2013). Peptidoglycan fragments stimulate resuscitation of "non- culturable" Mycobacteria. Antonie Van Leeuwenhoek Int. J. Gen. Mol. Microbiol. 103, 37-46. doi: $10.1007 / \mathrm{s} 10482-012-9784-1$

Nikitushkin, V. D., Shleeva, M. O., Zinin, A. I., Trutneva, K. A., Ostrovsky, D. N., and Kaprelyants, A. S. (2016). The main pigment of the dormant Mycobacterium smegmatis is porphyrin. FEMS Microbiol. Lett. 363, 1-8. doi: 10.1093/femsle/fnw206

Nikitushkin, V. D., Trenkamp, S., Demina, G. R., Shleeva, M. O., and Kaprelyants, A. S. (2020). Metabolic profiling of dormant Mycolicibacterium smegmatis cells' reactivation reveals a gradual assembly of metabolic processes. Metabolomics 16, 1-14. doi: 10.1007/s11306-020-1645-8

Nitzan, Y., Salmon-Divon, M., Shporen, E., and Malik, Z. (2004). ALA induced photodynamic effects on Gram positive and negative bacteria. Photochem. Photobiol. Sci. 3, 430-435. doi: 10.1039/b315633h

Olender, A. (2012). "Mechanisms of antibiotic resistance in Corynebacterium spp. causing infections in people," in Antibiotic Resistant Bacteria - A Continuous Challenge in the New Millennium, Vol. 15, ed. P. Marina (London: InTech).

Oliver, J. D. (2010). Recent findings on the viable but nonculturable state in pathogenic bacteria. FEMS Microbiol. Rev. 34, 415-425. doi: 10.1111/j.15746976.2009.00200.x

Olson, J. M., Nguyen, V. Q., Yoo, J., and Kuechle, M. K. (2009). Cutaneous manifestations of Corynebacterium jeikeium sepsis. Int. J. Dermatol. 48, 886888. doi: 10.1111/j.1365-4632.2008.03984.x

Patel, M., and Day, B. J. (1999). Metalloporphyrin class of therapeutic catalytic antioxidants. Trends Pharmacol. Sci. 20, 359-364. doi: 10.1016/S0165-6147(99) 01336-X

Plavskii, V. Y., Mikulich, A. V., Tretyakova, A. I., Leusenka, I. A., Plavskaya, L. G., Kazyuchits, O. A., et al. (2018). Porphyrins and flavins as endogenous acceptors of optical radiation of blue spectral region determining photoinactivation of microbial cells. J. Photochem. Photobiol. B 183, 172-183. doi: 10.1016/j. jphotobiol.2018.04.021

Porter, J., Edwards, C., and Pickup, R. W. (1995). Rapid assessment of physiological status in Escherichia coli using fluorescent probes. J. Appl. Bacteriol. 79, 399408. doi: 10.1111/j.1365-2672.1995.tb03154.x
Rickman, L., Scott, C., Hunt, D. M., Hutchinson, T., Carmen, M., Whalan, R., et al. (2005). A member of the cAMP receptor protein family of transcription regulators in Mycobacterium tuberculosis is required for virulence in mice and controls transcription of the rpfA gene coding for a resuscitation promoting factor. Mol. Microbiol. 56, 1274-1286. doi: 10.1111/j.1365-2958.2005.04609.x.A

Romanova, N. A., Brovko, L. Y., Moore, L., Pometun, E., Savitsky, A. P., Ugarova, N. N., et al. (2003). Assessment of photodynamic destruction of Escherichia coli O157: H7 and Listeria monocytogenes by using ATP bioluminescence. Am. Soc. Microbiol. 69, 6393-6398. doi: 10.1128/AEM.69.11.6393

Rook, G. A. W., Seah, G., and Ustianowski, A. (2001). M. tuberculosis: immunology and vaccination. Eur. Respir. J. 17, 537-557. doi: 10.1183/09031936.01. 17305370

Rossi, G. G., Guterres, K. B., da Silveira, C. H., Moreira, K. S., Burgo, T. A. L., Iglesias, B. A., et al. (2020). Peripheral tetra-cationic Pt(II) porphyrins photo-inactivating rapidly growing Mycobacteria: first application in mycobacteriology. Microb. Pathog. 148:104455. doi: 10.1016/j.micpath.2020. 104455

Roszak, D. B., and Colwell, R. R. (1987). Metabolic activity of bacterial cells enumerated by direct viable count. Appl. Environ. Microbiol. 53, 2889-2893. doi: 10.1128/aem.53.12.2889-2893.1987

Schmid, J., Hoenes, K., Vatter, P., and Hessling, M. (2019). Antimicrobial effect of visible light-photoinactivation of Legionella rubrilucens by Irradiation at 450, 470, and $620 \mathrm{~nm}$. Antibiotics 8:187. doi: 10.3390/antibiotics8040187

Shleeva, M., Goncharenko, A., Kudykina, Y., Young, D., Young, M., and Kaprelyants, A. (2013). Cyclic amp-dependent resuscitation of dormant Mycobacteria by exogenous free fatty acids. PLoS One 8:e082914. doi: 10.1371/ journal.pone.0082914

Shleeva, M., Kondratieva, T., Rubakova, E., Vostroknutova, G., Kaprelyants, A., and Apt, A. (2015). Reactivation of dormant "non-culturable" Mycobacterium tuberculosis developed invitro after injection in mice: both the dormancy depth and host genetics influence the outcome. Microb. Pathog. 78, 63-66. doi: 10. 1016/j.micpath.2014.11.016

Shleeva, M., Mukamolova, G. V., Young, M., Williams, H. D., and Kaprelyants, A. S. (2004). Formation of "non-culturable" cells of Mycobacterium smegmatis in stationary phase in response to growth under suboptimal conditions and their Rpf-mediated resuscitation. Microbiology 150, 1687-1697. doi: 10.1099/ mic. $0.26893-0$

Shleeva, M. O., Bagramyan, K., Telkov, M. V., Mukamolova, G. V., Young, M., Kell, D. B., et al. (2002). Formation and resuscitation of "non-culturable" cells of Rhodococcus rhodochrous and Mycobacterium tuberculosis in prolonged stationary phase. Microbiology 148, 1581-1591. doi: 10.1099/00221287-148-51581

Shleeva, M. O., Kondratieva, T. K., Demina, G. R., Rubakova, E. I., Goncharenko, A. V., Apt, A. S., et al. (2017). Overexpression of adenylyl cyclase encoded by the Mycobacterium tuberculosis Rv2212 gene confers improved fitness, accelerated recovery from dormancy and enhanced virulence in mice. Front. Cell. Infect. Microbiol. 7:370. doi: 10.3389/fcimb.2017.00370

Shleeva, M. O., Kondratieva, T. K., Goncharenko, A. V., Apt, A. S., and Kaprelyants, A. S. (2019a). cAMP-dependent transcription factor in Mycobacterium tuberculosis coded by the Rv3676 gene as a possible target for the development of antituberculosis drugs. Appl. Biochem. Microbiol. 55, 380-385. doi: 10.1134/ S0003683819030128

Shleeva, M. O., Savitsky, A. P., Nikitushkin, V. D., Solovyev, I. D., Kazachkina, N. I., Perevarov, V. V., et al. (2019b). Photoinactivation of dormant Mycobacterium smegmatis due to its endogenous porphyrins. Appl. Microbiol. Biotechnol. 103, 9687-9695. doi: 10.1007/s00253-019-10197-3

Shleeva, M. O., Kudykina, Y. K., Vostroknutova, G. N., Suzina, N. E., Mulyukin, A. L., and Kaprelyants, A. S. (2011). Dormant ovoid cells of Mycobacterium tuberculosis are formed in response to gradual external acidification. Tuberculosis 91, 146-154. doi: 10.1016/j.tube.2010.12.006

Shleeva, M. O., Mukamolova, G. V., Telkov, M. V., Berezinskaya, T. L., Syroeshkin, A. V., Biketov, S. F., et al. (2003). Formation of nonculturable cells of Mycobacterium tuberculosis and their resuscitation. Microbiology 72, 64-70. doi: 10.1023/A:1022230107266

Shleeva, M. O., Savitsky, A. P., Nikitushkin, V. D., Soloviev, I. D., and Trutneva, K. A. (2020). Effect of photodynamic inactivation against dormant forms and active growing cells of Mycobacterium smegmatis. Appl. Biochem. Microbiol. 56, 242-249. doi: $10.1134 / \mathrm{S} 000368382003014 \mathrm{X}$ 
Soriano, F., Huelves, L., Naves, P., Rodríguez-Cerrato, V., del Prado, G., Ruiz, V., et al. (2009). In vitro activity of ciprofloxacin, moxifloxacin, vancomycin and erythromycin against planktonic and biofilm forms of Corynebacterium urealyticum. J. Antimicrob. Chemother. 63, 353-356. doi: 10.1093/jac/ dkn491

Soriano, F., Zapardiel, J., and Nieto, E. (1995). Antimicrobial susceptibilities of Corynebacterium species and other non- spore-forming gram-positive bacilli to 18 antimicrobial agents. Antimicrob. Agents Chemother. 39, 208-214. doi: 10.1128/aac.39.1.208

Tauch, A., Kaiser, O., Hain, T., Goesmann, A., Weisshaar, B., Albersmeier, A., et al. (2005). Complete genome sequence and analysis of the multiresistant nosocomial pathogen. J. Bacteriol. 187, 4671-4682. doi: 10.1128/JB.187. 13.4671

Tholozan, J. L., Cappelier, J. M., Tissier, J. P., Delattre, G., and Federighi, M. (1999). Physiological characterization of viable-but-nonculturable Campylobacter jejuni cells. Appl. Environ. Microbiol. 65, 1110-1116. doi: 10.1128/aem.65.3. 1110-1116.1999

Trutneva, K., Shleeva, M., Nikitushkin, V., Demina, G., and Kaprelyants, A. (2018). Protein composition of Mycobacterium smegmatis differs significantly between active cells and dormant cells with ovoid morphology. Front. Microbiol. 9:2083. doi: $10.3389 /$ fmicb. 2018.02083

Trutneva, K. A., Shleeva, M. O., Demina, G. R., Vostroknutova, G. N., and Kaprelyans, A. S. (2020). One-year old dormant, "non-culturable" Mycobacterium tuberculosis preserves significantly diverse protein profile. Front. Cell. Infect. Microbiol. 10:26. doi: 10.3389/fcimb.2020.00026

van der Lelie, H., Hall, M. L., Van Mertens, M., Van Zaanen, H. C. T., Van Oers, R. H. J., Thomas, B. L. M., et al. (1995). Corynebacterium CDC group JK (Corynebacterium jeikeium) sepsis in haematological patients: a report of three cases and a systematic literature review. Scand. J. Infect. Dis. 27, 581-584. doi: 10.3109/00365549509047071

van der Meulen, F. W., Ibrahim, K., Sterenborg, H. J., Alphen, L. V., Maikoe, A., and Dankert, J. (1997). Photodynamic destruction of Haemophilus parainfluenzae by endogenously produced porphyrins. J. Photochem. Photobiol. B Biol. 40, 204-208. doi: 10.1016/S1011-1344(97)00057-2
Vanbosterhaut, B., Surmont, I., Vandeven, J., Wauters, G., and Vandepitte, J. (1989). Corynebacterium jeikeium (group JK diphtheroids) endocarditis: a report of five cases. Diagn. Microbiol. Infect. Dis. 12, 265-268. doi: 10.1016/0732-8893(89) 90025-4

Wang, C. C., Mattson, D., and Wald, A. (2001). Corynebacterium jeikeium bacteremia in bone marrow transplant patients with Hickman catheters. Bone Marrow Transpl. 27, 445-449. doi: 10.1038/sj.bmt.1702808

Wang, Y., Ferrer-Espada, R., Baglo, Y., Gu, Y., and Dai, T. (2019). Antimicrobial Blue light inactivation of Neisseria gonorrhoeae: roles of wavelength, endogenous Photosensitizer, oxygen, and reactive oxygen species. Lasers Surg. Med. 51, 815-823. doi: 10.1002/lsm.23104

Wilder-Smith, C. H., Wilder-Smith, P., Grosjean, P., Van Den Bergh, H., Woodtli, A., Monnier, P., et al. (2002). Photoeradication of Helicobacter pylori using 5aminolevulinic acid: preliminary human studies. Lasers Surg. Med. 31, 18-22. doi: 10.1002/lsm.10066

Wood, D. N., Chaussee, M. A., Chaussee, M. S., and Buttaro, B. A. (2005). Persistence of Streptococcus pyogenes in stationary-phase cultures. J. Bacteriol. 187, 3319-3328. doi: 10.1128/JB.187.10.3319-3328.2005

Zhang, Y. (2004). Persistent and dormant tubercle bacilli and latent tuberculosis. Front. Biosci. 9, 1136-1156. doi: 10.2741/1291

Zhang, Y., Yang, Y., Woods, A., Cotter, R. J., and Sun, Z. (2001). Resuscitation of dormant Mycobacterium tuberculosis by phospholipids or specific peptides. Biochem. Biophys. Res. Commun. 284, 542-547. doi: 10.1006/bbrc.2001.4993

Conflict of Interest: The authors declare that the research was conducted in the absence of any commercial or financial relationships that could be construed as a potential conflict of interest.

Copyright (c) 2020 Shleeva, Savitsky and Kaprelyants. This is an open-access article distributed under the terms of the Creative Commons Attribution License (CC BY). The use, distribution or reproduction in other forums is permitted, provided the original author(s) and the copyright owner(s) are credited and that the original publication in this journal is cited, in accordance with accepted academic practice. No use, distribution or reproduction is permitted which does not comply with these terms. 